Historia (Santiago), vol. 3, núm. SE, 2007.

\title{
The rights of the child in Chile: an historical view, 1910-1930.
}

\author{
Flores, Jorge Rojas.
}

Cita:

Flores, Jorge Rojas (2007). The rights of the child in Chile: an historical view, 1910-1930. Historia (Santiago), 3 (SE).

Dirección estable: https://www.aacademica.org/jorge.rojas.flores/2 ARK: https://n2t.net/ark:/13683/ppQy/4ve

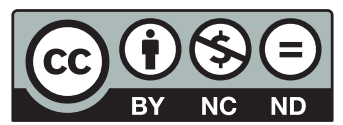

https://creativecommons.org/licenses/by-nc-nd/4.0/deed.es.

Acta Académica es un proyecto académico sin fines de lucro enmarcado en la iniciativa de acceso abierto. Acta Académica fue creado para facilitar a investigadores de todo el mundo el compartir su producción académica. Para crear un perfil gratuitamente o acceder a otros trabajos visite: https://www.aacademica.org. 


\title{
The rights of the child in Chile: an historical view, 1910-1930 ${ }^{1}$
}

\author{
Jorge Rojas Flores
}

Historian, teacher at Universidad de Talca and Arcis

\begin{abstract}
This article demonstrates that there was an early influence of children rights ideas in Chile between 1900 and 1930. These ideas were expressed through declarations that circulated in Chilean society and were variable. They ranged from those that demanded physical protection for children to those that pushed for a recognition of highest levels of autonomy of them. Even though these declarations did not have a solid supporting doctrine, they generated an impact in intellectual circles at the beginning of the twentieth century. The different opinions elaborated about children rights -opposing or supporting them- gave room to the establishment of public policies about the issue, which are presented in this work.
\end{abstract}

Key words: Rights of the child, infancy, protection of the child, infantile protagonism.

\section{Introduction}

The current debate about the rights of the child has rarely considered the historical course of this subject, with its tensions between different approaches, and the effects on the elaboration of public policies and the new experiences it influenced in the field of private life.

In this article we attempt to show a part of this course in Chile, between 1900 and 1930. In this timeframe the first proposals were made known and receptivity towards the incipient legal doctrine increased, though there were also resistances and criticism to the changes it implied.

Due to the diffuse and erratic presence of the subject, which didn't attain theoretical consistency, we will show its development through the texts that were known in the country, though not all of them were thought-provoking. In addition, we will review the atmosphere of acceptance and rejection to these ideas in the different areas related to infancy.

\section{The Rights of the Child}

The doctrine of the Rights of the Child has traveled a long road in West Europe, the United States and Latin America. Far from being a recent proposal, its roots go back to the $19^{\text {th }}$ century. This concept and its publication have had a surprising trajectory, with changing and zigzagging contents ${ }^{2}$.

In our continent, sensibility towards children was notably strenghtened during the second half of the $19^{\text {th }}$ century. At the beginning of the $20^{\text {th }}$ century the idea was already established - at least on an institutional level - that children had to be guaranteed a certain level of material and spiritual wellbeing. This didn't always mean that there was a strict recognition of rights; it often referred to the development of a feeling of compassion and mercy. However, the idea that because of their vulnerable and fragile condition children needed some kind of protection was soon linked to the concept of "rights". The influence of European culture, and later North American culture, was decisive in the difussion of this point of view.

Several authors are attributed with making the first reference to the rights of the child. The French revolutionary Jules Vallés (1832-1885), for instance, was one of the first to defend the rights of the child. His autobiographical The Child (1879) was a clear denunciation of the coercitive methods applied by the culture

\footnotetext{
${ }^{1}$ This article was written as part of the project "Experiences of children and concepts of infancy. Chile in the 1920s", Fondecyt N ${ }^{\circ}$ 1040660. I'm grateful for the bibliographical references supplied by Professor José María Borrás Llop and his student Marta Puig Ávila.

${ }^{2}$ One can consult a reconstruction of the concept of the rights of the child, from the end of the 19th century up to the end of the 20th, in the text by Philip E. Veerman, The Rights of the Child and the Changing Image of Childhood (The Netherlands, International Studies in Human Rights, vol. 18, Martinus Nijhoff Publishers, 1992). Emphasis is placed on the European Anglo-Saxon atmosphere.
} 
of the bourgeoisie and filled ranks with other literary works of that time that were equally sensitive to the subject, like that of Charles Dickens ${ }^{3}$.

But it was in the United States where a major development of the concept first arose. In 1892, the writer and teacher Kate D. Wiggin (1856-1923) published Childrens'Rights, in which she not only exposed the need to defend childrens rights, but also defined the specific contents of the concept. In her opinion, the rights of the child weren't the same as the concept of privilege or indulgence, but often the opposite of it. Children could be given many privileges, while their rights were not respected. This happened when underneath there was a belief that children belonged to their parents, who had unlimited power over them. According to the author, children -in their condition of human beings- belong to themselves and one of their inalienable rights was that of having a childhood. In practice, this right received boundaries when adults molded their children's conduct according to their own judgment and didn't allow them to have a space of their own, defined by the children's tastes and needs. For example, an excess of maternal zeal denied children the elemental right to "go dirty". Although the text by Wiggin wasn't translated into Spanish, it was known in Chile, as well as some of the author's children's stories ${ }^{4}$.

A little later, Ellen Key (1849-1926) would formulate converging ideas in her work The century of the Children (1900), which acquired remarkable notoriety in the West thanks to its translation into several languages. Though Key's central purpose was to expose the need to change the educational system predominant until then, she stated some ideas that would strenghten the notion of the rights of the child. For example, she defended "children's rights" to have a family united by love and harmony. That is to say, parents would live together in a "free union", not in one with discordance, forced by social convention. She also acknowledged the right of children to be born of healthy and robust mothers, preoccupied with their education; if women were not like that, it was preferable for them to renounce maternity. In education there had to be no punishments, the children's personalities had to be respected, and they had to be allowed to live in their own way, not obliged according to a model imposed by adults 5 .

Ellen Key was one of the first exponents of the new pedagogy that was under construction in those years. Through different ways, a new conception of childhood was spreading among educators, psychologists and pediatricians. Many of them included the idea of the rights of the child in their views, though they didn't always say this explicitly, nor did they understand the pedagogical reform in the same way. In the United States John Dewey (1859-1952) clearly divulged the concept of active citizenship in schools, though his theoretical contribution wasn't centered on conceptualizing the subject of the rights of the child ${ }^{6}$. Maria Montessori (1870-1952) applied a pedagogical method that acknowledged the child's peculiarity and individuality, as well as the differentiated development of his capacities and his natural tendency to enjoy the learning process ${ }^{7}$.

Paul Robin (1837-1912) and Sébastien Faure (1858-1942) didn't only conceive a libertarian pedagogy; they also applied it in the institutions they ran. Here, the leading role of children acquired preponderancy, within a perspective of democratization and emancipation of the individual. In Spain, Francisco Ferrer (1859-1909) also embarked on the libertarian view. His proposal included the developent of the child's initiative and critical sense, equalitarian, solidary and cooperative relationships, as well as respect of freedom of expression ${ }^{8}$. Also in Spain, one of the divulgators of active pedagogy was Fernando Sainz, who in 1929 published a book titled Los derechos del niño (The rights of the child) ${ }^{9}$. In Poland, Janusz Korczak (pseudonym of Henryk Goldszmit), a pediatrician and children's books writer, wrote two works that revealed his fervent defense of children's rights: How to Love a Child (1919) and The Child's Right to Respect (1929). Besides his writings, Korczak did an experiment of applying self government in a children's asylum he ran ${ }^{10}$.

The new pedagogy also reached tsarist Russia. After the breakout of the bolchevist revolution (and before the consolidation of Stalinism), there was growing enthusiasm to turn education into one of the constituent pillars of socialist society, where children would have a new status. Several pedagogical tendencies clashed in this fertile field. A few months before the onset of the revolution, in a convention of

\footnotetext{
${ }^{3}$ Through the main character of the book, a child facing a conflicting relationship with his parents, Jules Valles set out his own declaration of intentions: "I will defend the rights of the child just like others defend the rights of man" ("je défendrai les Droits de l'Enfant comme d'autres les Droits de l'Homme", cap. XXV). This phrase is cited as one of the forerunners in the subject of the rights of the child.

${ }^{4}$ Kate Douglas Wiggin, Children's rights. A book of nursery logic (Boston-New York, Houghton Mifflin Co., The Riverside Press Cambridge, 1892). This text is to be found in the National Library in Santiago, as well as other literary works by the author.

${ }^{5}$ Let us remember that Key was distant from the catholic faith and expressed herself in favor of divorce. There was a spanish edition: Ellen Key, El siglo de los niños (Estudios) (2 volumes, Barcelona, Biblioteca Sociológica Internacional, Imprenta de Henrich y Comp. en C. Editores, 1906).

${ }^{6}$ Among his works, the following stand out: My Pedagogic Creed (1897); The School and Society (1899); Ethics (1908); How We Think (1910); Democracy and Education (1916); Essays in Experimental Logic (1916); Reconstruction in Philosophy (1920); Human Nature and Conduct (1922); Experience and Nature (1925); The Public and Its Problems (1927); The Quest for Certainty (1929).

Among her works: El método Montessori (1912); Antropología pedagógica (1913); Método avanzado Montessori (2 vols., 1917); El Método de la Pedagogía Científica, (1928); Ideas Generales sobre mi Método (1928); El niño en la Iglesia (1929), La misa explicada a los niños (1932), Paz y Educación (1934); El secreto de la infancia (1936), y Manual de pedagogía científica, (1936).

${ }^{8}$ Jorge Rojas Flores, Moral y prácticas cívicas en los niños chilenos, 1880-1950 (Santiago, Ariadna Ediciones, 2004), pp. $244-246$.

9 We haven't been able to consult the book. We obtained the title from the catalogus of the Nacional Library of Spain on http://www.bne.es

${ }^{10}$ Veerman, The Rights of the Child, pp. 93-110. There is a useful bibliography by Betty Jean Lifton, The King of Children. The Life and Death of Janusz Korczak, to be obtained at http://korczak.com/Biography/kap-0.htm The biography can also be consulted on Wikipedia: http://en.wikipedia.org/wiki/Janusz_Korczak
} 
proletarian culture (that took place in Moscow in February 1918), the Association for Free Education presented a draft of the Declaration of the Rights of the Child, that was not approved, due to its excessive "individualistic" approach. The text consisted of 17 items, some of them quite innovative. For example, it was stated that all children were their own proprietor, and could not be considered to be property of their parents, society nor the State ( $3^{\text {rd }}$ article). Each child had the right to choose his closest educators, and to break away from his parents if these were bad educators $\left(4^{\text {th }}\right.$ article). No child could be forced to remain in an educational institution $\left(6^{\text {th }}\right.$ article). No one (including parents, society and the State) could force a child to be instructed in a particular religion or to practice its rites. Religious education had to be freely chosen by each child $\left(12^{\text {th }}\right.$ article). Every child had the right to form organizations and associations, with other children or adults $\left(15^{\text {th }}\right.$ article). From infancy onwards and according to their talents and abilities, children had to take part in an educational work for community's good, which should not impede their physical health or spiritual development. This would allow them to feel like an active member of society and a constructor of their own lifes, and not like a "parasite"11.

The ideas expressed by Wiggin, Key and the Association for Free Education were a foreboding of what would later on become the modern concept of the rights of the child, often with a more radical character. However, for many decades, these ideas weren't developed mainly in that direction. On the contrary, the situation criticized by Wiggin prevailed; that is to say, a protection of childhood that did not always acknowledge its rights. There is an example of this tendency in the reform to the judicial system modeled after that of North America; this reform excluded minors from penal jurisdiction and created a system of protection for helpless children. This system was ambiguous: it had a modern and benevolent aspect (removal of punishment, implementation of educational methods with a scientific basis), but at the same time, it was applied in a discretional and ample way, which denied basic rights ${ }^{12}$. At the other extreme, abusive pedagogical doctrines were formulated ${ }^{13}$ with authoritative paternalism under the order of defending "the child's good".

During the first decades of the 20th century the juridical doctrine based on individual rights was displaced by modern views that proclaimed economical and social rights. There were important precedents in the constitutions of Mexico (1917) and Germany (Weimar, 1919), and foremost in the labor conventions promoted by the constitution of the OIT (1919) that commited the signing states. Some of those first international norms protected children workers. In that sense, the movement in favor of children's rights was linked to an atmosphere (notably convulsed) that was more and more willing to give the State a central function in the protection of social and economic rights.

But the first documents that declared the rights of the child, as we will see later on, weren't only an extension of this movement. In a sense, they went further than the simple application of assistential mechanisms to guarantee certain material benefits to the weakest. They also intended to defend the childrens spiritual needs (which were left out in the case of the social and economic rights of adults), besides emphasizing the attainment of happiness in children as an indisoluble whole.

\section{The rights of the Child in Chile}

Several authors and texts that defended the rights of the child were known in Chile; some were institutional, others personal, and they had different levels of difussion and influence. Ellen Key's book circulated amongst the intellectuals of the beginning of the century, though it did not attain the diffussion of the works of John Dewey, Adolphe Ferriere and other exponents of the new pedagogy. In the libertarian field, Francisco Ferrer was without doubt the predominant figure, though left out by official circles. Under his influence, the Workers Federation of Chile (Federación Obrera de Chile) and the Communist Party created rationalist schools that developed to a certain level between 1921 and $1926^{14}$.

Among the institutional texts that expressly proclaimed the rights of the child, four were known in Chile between 1910 and 1930: the agreement of a scientific conference in Spain in 1912; the famous declaration of Geneve, signed by the Society of Nations in 1924; the text signed in Montevideo by the delegates of ten countries, including Chile in 1927; and the Declaration of Washington of $1930^{15}$.

\footnotetext{
${ }^{11}$ The text is extensibly cited in Veerman, The Rights of the Child, pp. 435-437.

12 The evaluation about this particular subject has been notoriously critical, though in its time the new system of protection was presented as an expression of the progress of nations. About this, see Anthony Platt, The Child Savers. The Invention of Delinquency (Chicago, The University of Chicago Press, 1977)

${ }^{13}$ An example of this is to be seen in the book by the psychologist Alice Miller, For your own good: Hidden Cruelty in Child-Rearing and the Roots of Violence (Farrar, Straus, Giroux, 1983), centered on the methods of childrearing and education in Germany from the $19^{\text {th }}$ century onwards.

${ }^{14}$ Emilio Uzcátegui García complained about the little spreading the ideas of Key, Tolstoi and Ferrer had in the training of teachers. To reverse this, he wrote Los pedagogos de la libertad (Iquique, no editorial, 1923/1924).

15 There were probably other declarations circulating but we have found no trace of them. For example, the text by the Uruguayan educationalist José H. Figueira from 1910 and reedited in 1927 and 1939 was apparently only known locally. However, we will cite him again further on as he seemed to influence the declaration written by Rodríguez Fabregat. Another famous Uruguayan, Clemente Estable, presented a text organized as a Decalogue in 1928. Both are mentioned in a document of INN, La inclusión de la niñez con discapacidad (Montevideo, workdocument of PRODER, IIN, July 2001). The Chilean Amanda Grossi mentions an initiative that circulated in the First International Conference of Social Economy, that took place in Buenos Aires in 1924 (October $26^{\text {th }}-$ November $\left.4^{\text {th }}\right)$. The text was supposedly ratified in Lima, during the Third Scientific Pan American Conference, that took place between December 1924 and January 1925. Amanda Grossi Aninat, Eugenesia y su legislación (Santiago, extended paper to apply for
} 
The first of these declarations was one of the conclusions of the First Spanish Conference of School Hygiene, which took place in Barcelona in 1912 (April 8-12). Though this conference was dedicated to various matters related to the promotion of hygiene in schools, the subject that was most diffused was that of the "Rights of the Child", which was probably an initiative promoted by the eminent pediatrician Manuel Tolosa Latour ${ }^{16}$. In November 1912 a socialist newspaper of Iquique called El Despertar de los Trabajadores (The Workers Awakening) made an ironic comment about the declaration ${ }^{17}$. The following year, the text was reprinted in Revista de Higiene Práctica (Magazine of Practical Hygiene) ${ }^{18}$. In 1914 it was reprinted, this time in La revista azul (The blue magazine), an "illustrated bimonthly of the home and domestic economy", aimed at women of the upper classes, though the origin of the text wasn't mentioned ${ }^{19}$. Apparently, this declaration had ample circulation in Latin America and not only in Chile. ${ }^{20}$

The text proclaimed in Barcelona in 1912 consisted of eight articles preceded by some aclaratory paragraphs to uphold its contents. The first articles shed light on the hygienist atmosphere that prevailed at the congress, but the last ones show how, among scientists, the romantic ideal of infancy that associated childhood with happiness, had caught on. The text proposed:

1- The right to sunlight;

2- The right to abundant air;

3- The right to water and cleanliness (children could not be confined inside closed spaces, without light, water, and cleanliness)

4- The right to sustenance ("secure the necessary food")

5- The right to physical activity ("healthy exercise")

6- The right to joy (" that their organisms expand"; right to a "healthy recreation and joy for children");

7- The right to love ("love that boost their moral life"; the text considered it to be a crime to flagellate a child or to raise him surrounded by sadness. It even recommended a punishment of one to three years in prison for those who hit children with the knuckles, rulers or other instruments);

8- The right to truth ("to nourish their intellectual activity", lies in any way are a crime) ${ }^{21}$

According to the text, many of these rights had to be guaranteed by the family, and subsidized by the state. That is to say, it proposed to create institutions that would fulfill these aims. The focus of this declaration mixed several ingredients. Five of eight articles referred to the physical protection of children, two to emotional aspects (love and joy) and one was of moral character.

Some years later, another text written in Europe had a large international circulation, despite its more restrictive content in comparison to the document aproved in Barcelona. The initiative was initially promoted in England by Eglantyne Jebb (1876 - 1928), who wrote the text. She had founded the Save the Children Fund in London in 1919 with her sister Dorothy. Influenced by this, a homologous institution, Radda Barnen, was created that same year in Sweden. A little later, in January 1920, a new organization was formed in Geneva with the help of the Red Cross, Save the Children International Union ${ }^{22}$. This institution took on the declaration in February 1923 and proclaimed it officially on may $17^{\text {th }}$ of the same year. Already in that time, the text was known as the "Declaration of Geneva". In several solemn ceremonies, the text was endorsed by outstanding persons (among them, Ellen Key) and European monarchs. During one of these acts, on november 21th 1923, the declaration was read from the Eiffel Tower by radio by Gustave Ador, president of the Swiss Confederation and of the International Commitee of the Red Cross ${ }^{23}$.

Composed by five principles, the declaration indicated the essential conditions that assured the total development of children. The text read:

"Governments, men and women of all nations, recognizing that mankind owes to the Child the best that it has to give, declare and accept it as their duty that beyond and above all considerations of race, nationality or creed:

i. The child must be given the means requisite for its normal development, both materially and spiritually.

Bachelor's Degree at the Faculty of Political and Social Sciences, Universidad de Chile, Editorial Nascimento, 1941), p. 180. We have no further references about this text.

${ }^{16}$ In spain, the text was published in Pro-Infantia (Bulletin of the Higher Council of Protection to Infancy and Repression of Mendicity) №40, agosto/1912, pp. 501-502. About the role of Tolosa, María Luisa Ramas Varo, La protección legal de la infancia en España: orígenes y aplicación en Madrid (1900-1914) (Madrid, Consejo Económico y Social, 2001), cited by María Belén Rodrigo Lara, La libertad de pensamiento y creencias de los menores de edad (Madrid, Doctoral Thesis, Universidad Complutense de Madrid, Facultad de Derecho, Departamento de Derecho Eclesiástico del Estado, 2004), pp. 65-66.

17 “A los niños pobres" (Juan Cordero), in El Despertar de los Trabajadores, Iquique, November 24, 1912, p. 1.

${ }^{18}$ Revista de Higiene Práctica, no number, 1913, pp. 134-135.

${ }^{19}$ La revista azul, $\mathrm{N}^{\circ} 1$, November 1914, p. 20

${ }^{20}$ In 1916, in a magazine published in Medellín there was mention of the Rights of the Child that were proclaimed in this Conference. Carlos Edward García Londoño, Niños trabajadores y vida cotidiana en Medellín, 1900-1930 (Medellín, Clío, Editorial Universidad de Antioquia, 1999), pp. 63-64.

${ }^{21}$ La revista azul, $\mathrm{N}^{\circ} 1$, November 1914, p. 20

${ }^{22}$ Also known as UISE, Union Internationale de Secours aux Enfants, or International Save de Children Union. In 1946 this institution was named International Union for Child Welfare, IUCW.

${ }^{23}$ Veerman, The Rights of the Child, pp. 87-91 and 155-159. 
ii. The child that is hungry must be fed, the child that is sick must be nursed, the child that is backward must be helped, the delinquent child must be reclaimed, and the orphan and the waif must be sheltered and succoured.

iii. The child must be the first to receive relief in times of distress.

iv. The child must be put in a position to earn a livelihood, and must be protected against every form of exploitation.

v. The child must be brought up in the consciousness that its talents must be devoted to the service of its fellow men." ${ }^{24}$

As one can see, the Geneva Declaration emphatized the material protection of the child in quite a pragmatic and concrete way, in comparison with the aspects considered in the Spanish declaration that was more ample but had a more lyrical tone. The right to play, happiness, love, authonomy and "to go dirty", which had already been considered in other initiatives, weren't mentioned here. There was also no mention of a "subsidiary" responsibility of the State, in the defense of these rights. Of course, the text by Jebb was far from that by Wiggin in 1892, or of the document presented in Mowcow in 1918.

Under the influence of the Save the Children International Union, the fifth assembly of the Society of Nations finally agreed in September 1924 in Geneva to adopt the Declaration of the Rights of the Child, without modifying the text. The Chilean delegates were Armando Acharán, Enrique Villegas and Jorge Valdés.

In Chile, these agreements had a discreet circulation. Initially the news went unnoticed in comparison to other inernational facts that captured the headlines of the press. But, a little later, the orgnizations associated to the Declaration that had a presence in Chile put some attention on the subject. In May 1924, the Chilean government approved the regulation of the Youth Red Cross, and with this, according to the Red Cross, adhered to the Declaration of Geneva ${ }^{25}$. In April of that year the delegate of the Geneva based Save the Children International Union, Suzanne Ferriere, visited Chile to establish institutional contacts and request cooperation for the Chilean Red Cross, the society that corresponded to the one she represented ${ }^{26}$.

The Union International de Secours aux Enfants sent a parchment with the Declaration of the Rights of the Child to the IV Congreso Panamericano del Niño (IV Pan American Convention of the Child), that took place in Santiago in 1924, to be signed by the delegates. During the closing ceremony the initiative was approved by unanimity and the assisting delegates signed their adherence to the Declaration of Geneva. In the same occassion, they adhered to the Brussel based International Child Protection Office ${ }^{27}$.

Some time before, in August 1924, the writer Ángel Custodio Espejo mentioned in the press the Rights of the Child proclaimed in the Declaration of Geneva. In an article, he showed the need to accompany this declaration with practical agreements effectively headed to guarantee the protection of the child, which he hoped would happen during the Pan American Convention of the Child ${ }^{28}$. The declaration wasn't mentioned much in the years thereafter. However, in 1927 Vicente Alfredo Riquelme commented on the rights of the child in an article published in the Revista de Educación Primaria (Magazine of Primary Education). This is important because it was a periodical of ample circulation among teachers. In the author's opinion, the movement in favor of infancy had intensified in Europe as a consequence of the war and had led to a true "cult of the child", and many wills had united in this phenomenon. In short, children had a right to be well born (that is to say, the well being of the mother had to be secured), to live well (brought up according to scientific criteria) and to be well educated (a complete training for life). This meant that a series of changes had to be introduced in institutions and the minds of people ${ }^{29}$.

Between 1928 and 1931 and in three occasions, the Youth Red Cross magazine, Yo sirvo (I serve), published the Declaration of Geneva that had been adopted by the International Red Cross in 1923. This seems to have been the most massive means of circulation the declaration had, as it was largely distributed in schools $^{30}$.

At the same time, there was an initiative on South American level that had its origin in the new institutional environment in favor of infancy. Let us remember that during the second American Convention

\footnotetext{
${ }^{24}$ We transcribe the text published in Antecedentes, actas y trabajos del Cuarto Congreso Panamericano del niño, celebrado en Santiago de Chile en el Palacio del Congreso Nacional, los días 12 a 19 de octubre de 1924 (from now on Cuarto Congreso Panamericano) (Santiago, Imprenta Cervantes, 1925), volume.I, pp. 148-149.

${ }^{25}$ Though it was brought up like this, we don't know how these facts were related. Decree 1379, May 7th 1924, Ministery of Public Instruction. Cited in Yo sirvo, №4, June 1930, p.84 (the text indicates erroneously March instead of May). This adhesion is also mentioned in a list of ephemerides published in Yo sirvo, $\mathrm{N}^{\circ} 1-2$, March-April 1931 (back cover)

${ }^{26}$ The press translated the institution with the name Unión Internacional de Socorro al Niño (International Union of Aid to the Child). Among the interviews by Ferriere there was one with the

La prensa tradujo la institución con el nombre de Unión Internacional de Socorro al Niño. Entre las entrevistas que desarrolló Ferriere estuvo una con el National Board of Infancy. El Diario Ilustrado, Santiago, July 21, 1924, p.10.

${ }^{27}$ El Mercurio, Santiago, October 19, 1924, p.13. Cuarto Congreso Panamericano, volume.I, pp. 95-96, 101 and 148-149.

28 "La protección del niño" (Angel C. Espejo), in El Mercurio, Santiago, August 10 1924, p.5.

${ }^{29}$ Revista de Educación Primaria, No6-7, August-September 1927, pp. 239-243.

${ }^{30}$ Yo Sirvo, Nº1, October 1928, back cover; N¹1, October 1929, back cover; No4, June 1930, p.84. In Revista de Salud Pública, published by the chilean Red Cross between 1922 and 1924, no mention was made of the declaration.
} 
of the Child, that took place in Montevideo in 1919, it was agreed to form a permanent body to promote infancy policies in the continent, under the name of International American Office of Protection of Infancy, with headquarters in the capital of Uruguay. The promotor of this idea was the Uruguayan pediatrician Luis Morquio, who committed himself to obtaining the support of his country's goverment to put the initiative into practice. There were no achievements prior to the next convention, which was set to take place in Rio de Janeiro (1922). Therefore, in Rio the Chilean delegate Cora Mayers insisted on the declaration of intentions. From then on Morquio had more support. In July 1924 he achieved his purpose when the Uruguayan government finally created the Office under his honorary direction. This resolution had to be ratified by the other American nations. The proposal, which included a regulation, was presented for consideration of the IV Convention, celebrated in Chile in October of that same year.

During that meeting, the creation of the new organization was approved under a new name: Instituto Internacional Americano de Protección a la Infancia (International American Institute of Protection of Infancy). Talks went on in the following years, conducted by a provisory council, and in June 1927 ten countries signed the official constitution of the Institute in Montevideo, which would be directed by Dr. Luis Morquio $^{31}$.

During the inaugural session of the Institute, on June 9th 1927, the Decalogue of the Rights of the Child was approved, after an initiative of the Minister of Public Instruction of Uruguay, Enrique Rodríguez Fabregat. In his inspired speech, the minister incited "all men of good will and sane heart to consider this declaration of the Rights of the Child, this Table of Rights in which lies the secret of the greatness and glory of nations and peoples".

\section{"DECLARATION OF THE RIGHTS OF THE CHILD}

Table of the Rights of the Child in which lies the progress of the peoples:

1. The right to life. The sum of all rights is given for the only reason of having been born. Right to a house to live, to maternal attention, to the obligatory recognition by the father, with all the obligations paternity imposes, to the supervision of the State for his development and physiological prosperity.

2. The right to education. First assistance to nursery schools, kindergarten. Second cycle: Primary School. Abolition of the city schools system. Abolition of bookish teaching based on memorization.

3. Reintegration of the child to nature, through a school of activity, of work, joy, -school parks- to attain the reactions of body and soul, - health, intelligence and emotion, -and to prepare the workers for his own destiny and social greatness.

4. The right to specialized education. Health schools, in the open air, with woods, grass, in sunlight, for the abnormal, retarded, the sick and the weak.

5. The right to maintain and develop the own personality. A study of vocations, systems of spiritual orientation without artifice, that can only be attained in the School Parks, in nature, as a reaction of the individual's intimacy to external life. An acknowledgement, in the practice of educational systems, of the right to be a child, to live and feel as such, free of the cold artificiality of the cloister school and its dogma.

2.- Derecho a la educación. Primera asistencia a los Jardines de Niños, Kindergarten. Segundo ciclo: escuela primaria. Abolición del sistema de escuelas de ciudad. Abolición de la enseñanza verbalista y libresca. Reintegración del niño al seno de la naturaleza, por medio de una escuela de actividad, de trabajo, de alegría, Parques Escolares, - para lograr las reacciones de cuerpo y alma, - salud, inteligencia y emoción, - y preparar los obreros de su propio destino y de la grandeza social.

5. The right to complete nutrition. A mother's right to rear her child. A State insurance for the mothers without means. Free milk. Lunch for schoolchildren. Refectory schools for minors that are working before the full fulfillment of this table of rights.

6. The right to complete economic asistance. This means that parents are obliged to guarantee the child has an economic situation with no anguish (if this isn't possible, the State has this obligation). The right to housing, clothing, to all oportunities of wellbeing that man's work offers for the world's progress.

7. The right to earth. Earth to live on. An acknowledgement of the child's right to take up his place in the world, for the sole reason of having been born. In the School Parks, earth is put to his disposition for the development of his energies, his vital impulse, of his interests, his abilities to observe, to learn for himself in the vast universe and to understand that life is an unchanging law of solidarity in the effort of creation.

Derecho a la vivienda, al vestido, a todas las oportunidades de bienestar que el trabajo del hombre pone al servicio del progreso del mundo.

8. The right to social consideration. Everything for the child. Abolition of the legal distinction between lawful and unlawful children. The child, is just child. The child has a right to his parents. Transformation of orphanages and reform institutions, where the "ward" system destroys personality, into family colonies of education and work, organized in small social nucleus and entrusted to a father and mother that add to the affection of their own children, that of a small group of homeless children.

\footnotetext{
${ }^{31}$ Later on, this institution became the Interamerican Institute of the Child. Antecedents and constitution of the Institute in Boletín del Instituto Internacional Americano de Protección a la Infancia (from now on BIIAPI), Nº1, July 1927, pp. 7-14 and 29-66.
} 
9. The right to joy. Acknowledgement of this right without conditions, that is expressed in family life with no economic anxiety, in active school in contact with nature, in an education with no ruse, at table with bread, in the home with hearth. The right to air and light, to the earth that is sowed, to fire that warms and water that purifies. The right to be a child who will become a man, to form with a healthy body and clean soul the workers of freedom, the architects of the world's conscience.

10. The sum of these rights of the child forms the integral right: the right to life. Of its acknowledgement and observance depends the greatness of the peoples. Health, joy, the formation without impediment of children for culture, for work, for freedom and cooperation are the basis for the values of man's destiny in a new phase of History" 32 .

As can be seen, the text combined both a traditional and an innovative view. For example, it considered the child's education and his material protection (economic security, the right diet, sanitary conditions). It didn't advocate any type of education, as the declaration defended an active pedagogical model, not one based on books. It also included the right to "social consideration", expressed in legal equality (elimination of the difference between lawful and unlawful children), as the right to maintain and develop the own personality and focus his energies (which implied criticism to the traditional model of asylums and reformatories). In other aspects the text is ambiguous, as it states the right to joy, but with a stronger emphasis on material wellbeing.

Though we don't know the exact origin of this text, we can supose that Rodríguez Fabregat saw the Decalogue of the Rights of the Child published by José H. Figueira in 1910. It is similar in its structure and contents ${ }^{33}$.

Since the founding of the International American Institute and the declaration signed in Montevideo, the idea of conceding rights to children began to spread more in Latin America. In fact, during the 1930 Pan American Convention of the Child, which took place in Lima, there was a discussion about the need to include an explicit reference to the protection of chidren in the internal legislation of every country. After a large debate, the first code of the child was enacted in Uruguay in $1934^{34}$. The text of 1927 didn't establish a legal obligation for the signing States; it consisted of a series of agreements in which official representatives of the States participated, and thus, commited the wills of the governments. However, in Chile, the circulation of the agreement signed in Montevideo was limited. Neither the The press creation of the new Institute nor the signing of the Decalogue of the Rights of the Child received much coverage from the press ${ }^{35}$. According to one author, physicians took on the Decalogue in May 1928. If this was so, it must have been Luis Calvo Mackenna who influenced this agreement ${ }^{36}$.

During the first International Convention of Teachers, that was held in Buenos Aires in January 1928, the subject of the rights of the child circulated again. In fact, the declaration approved in Montevideo in 1927 was presented during the teachers meeting by the minister of Public Instruction of Uruguay, Enrique Rodríguez Fabregat ${ }^{37}$. Again, the Chilean press scarcely informed of the agreements of the teachers' convention, because of the hostile attitude that existed towards the official delegation, which dulled the content of the resolutions. No other thing could be expected; the convention was to be held in Santiago originally, but the political persecutions that had started in February 1927 forced to move it to Buenos Aires (despite a fleeting rapprochement between the General Association of Teachers and the government of Ibañez). The press, which was controlled by the government censorship, did not highlight the meeting ${ }^{38}$.

\footnotetext{
32 The complete texto is transcribed in BIIAPI, $\mathrm{N}^{\circ} 1$, July 1927, pp. 39-41.

${ }^{33}$ The text by José H. Figueira, from 1910, read:

1. - The child has a right to be well born. That is to say, to be a healthy and legitimate child (Eugenesic and moral right).

2.- The child has the right to dispose of everything he needs for his complete and normal development: healthy and enough food, clean and appropriate clothing, dry and cheerful home, with plenty of air, light and sun. An integral education that puts him progressively in possession of the cultural inheritance of the race and its essential and lasting values (Hygienic and cultutal right). 3.- The child has a right to the affection and protection of his parents and the moralizing example of his home.

4.- The child has a right to freedom in his physical and mental development. To fulfill his own life to form his character and his conscient personality, which contribute to social progress. For now the only limit and while the nature of infancy isn't better known, is to prevent, compensate, inhibite and lastly repress all manifestation that is damaging to the individual and society. 5.- The child has a right to recreation, to play and to the joy of living.

6 .- The child that is weak, physical and mentally subnormal, the orphan and the abandoned child, have a right to the tutelage and the care of the community and the State (Open door schools, vacation colonies, school parks, reeducation homes, etc.)

7 .- The child and the youngster have the right to a cultural and technical - industrial education, at least until the age of 16 . To this end, the aptitudes and vocational abilities of the youngster will be determined at the age of 12, indicating the technical or industrial school that is most convenient for him.

8 .- The child has the right to protection against all exploitation and bad treatment.

9 .- The insubordinate child or the child that has gone astray must be corrected according to a special system of medical pedagogical reeducation.

10 .- All children, regardless of their race and social condition have the same essential rights (Natural right of potential equality). The text is cited by his son Gastón Figueira, in the article "José H. Figueira frontrunner of the rights of the child", to be seen on the website http://www.perfiluruguayo.com/anoranzas_y.html

${ }^{34}$ The subjects tackled in the VI congreso were transcribed in the Revista Chilena de Pediatría, №5, May 1930, pp. 272-279. The first project of the Uruguayan Code of the Chile was presented in 1925. This reference was given to me by historian María Eugenia Jung.

${ }^{35}$ A brief reference in the briefs section of La Nación, Santiago, 10 June 1927, p.13.

${ }^{36}$ Grossi, Eugenesia, p. 181. The agreement isn't mentioned in Revista Médica de Chile

37 The news was published in El amigo magazine, Santiago, Nº72, February 1929, p.23.

${ }^{38}$ The chilean delegation was directed by César Godoy Urrutia. The international meeting was tense because of the withdrawal of some delegations and several accusations. There are brief news about the convention in La Nación, Santiago, 10 and 12 January 1928.
} 
Gabriela Mistral, who assisted to this convention, presented a paper titled "The Rights of the Child", which had more coverage abroad than in Chile ${ }^{39}$. Besides the impact of this text at the time, it is interesting to know its contents:

1. "The right to complete health, vigor and health"

2. "The right to trades and professions", that is to say, that intelligence governs societies, regardless of the class it comes from.

3. "The right to the best of tradition, to the best of tradition, that in western peoples, in my opinion, is christianity"

4. "A child's right to maternal education"

5. "The right to freedom, a right the child has before it is born, with free and equalitarian institutions"

6. "The right of the South American child to be born under laws of decorum", that mark no difference between children (without mentioning it, she referred to lawful and unlawful children).

7. "The right to secondary education and part of upper education" 40.

Behind this text there was a peculiar concept of the rights of the child, based on the exceptional character of infancy. Gabriela Mistral stated it clearly:

"Infancy served abundantly and even excessively by the State, should be the only luxury - that is to say, squandering - that an honest society should allow itself, for its own honor and enjoyment. Infancy deserves every privilege. I would say it is the only entity that can receive - without a grumble of the mean - that which is so hateful, and at the same time so useful of our society, that is called "privilege". And while infancy lasts, it is understood, children can live in a natural state of hoarding the excellent and pure things of the world, in total enjoyment. This is a kind of loan by God to the ugliness and meanness of our life, to excite us, with each generation, to build a more equitative and spiritual society" 41 .

This doesn't mean that there wasn't an acknowledgement of the strong bond between the status of infancy and the situation of society as a whole. Mistral herself noted that nothing mobilized adults with such impetus as infancy did. This had to be taken into consideration, as the problem of infancy wouldn't be remedied if the social problem as a whole wasn't remedied at the same time. In the middle of big social conflict, the subject of infancy had the virtue of being able to unite the biggest adversaries: "even the worst raise their heads, listen, become noble and welcoming in a moment, when the child is mentioned"

At the end of the period we are studying, the conclusions of the Conference of the White House about Health and Protection of the Child in Washington (November 1930) were made public. The text included a declaration of the rights of the child (known as Children's Charter), that was published the next year in the bulletin of the International American Institute of Protection of Infancy. When it took place, the Chilean press didn't pay attention to the conference. Apparently the text didn't have a large circulation in Chile ${ }^{43}$

The ideas surrounding the rights of the child between 1910 and 1930 did not have a definitive orientation, nor did they constitute a coherent doctrine. As can be seen in the texts, they all considered the need to fulfill basic, material needs. All of them also considered the access to education. A few embarked towards more subjective spheres, including the right to happiness. Only a few texts included the right to equality and no discrimination. And almost overall there was an absence of the recognition of childrens autonomy, except in those who, under libertarian inspiration, questioned the power exerted by teachers and parents.

\section{Reception}

In Chile, the reception of the ideas about infancy circulating in Europe and the United States was partial, and sometimes its development can only be traced in an indirect way. As we shall see later on, resistances were stronger on some topics and the changes were slow to take on. However, there were profound innovations in certain areas, for example in the legal sphere. These transformations weren't only based on a new concept of infancy, but also on a change in the concept of the State.

In several countries the rearing of children became part of the public sphere of action when the paternal function was neglected or clearly went against society's expectations. In this manner, paternity lost its inviolable private character and the care of children became a matter with social implications.

In 1855 the civil code had established a frame of rights and obligations between parents and children that gave the former ample atributions. These attributions were altered with the enactment of the Law of

\footnotetext{
${ }^{39}$ For example, the text was published in Boletín de la I.M.A. $\left(\mathrm{N}^{\mathrm{o}} 1,1928\right)$ edited in Buenos Aires by Internacional del Magisterio Americano; also in Amauta (N¹2, February 1928, p.32), the peruvian magazine directed by Mariátegui (next to the text of Rodríguez Fabregat, p.33) and in the weekly Repertorio Americano, of Costa Rica (ํo7, August 18, 1928, pp.106-107).

${ }^{40}$ Gabriela Mistral, Magisterio y niño (a selection of prose with a prologue by Roque Esteban Scarpa, Santiago, Editorial Andrés Bello, 1979), pp. 62-65.

${ }^{41}$ Mistral, Magisterio y niño, p. 62.

${ }_{42}^{4}$ Mistral, Magisterio y niño, p. 63.

${ }^{43}$ Among other things, the novelty of this declaration was that it included the right to "be understood"; to be protected from work that prevents his physical and mental development, limits his education and deprives him from the right to comradeship, joy and play; to give relief and education to blind, deaf or crippled children, and to give protection and care to intellectually subnormal children. The conference (White House Conference on Child Health and Protection) took place between 19 and 22 November 1930. BIIAPI, N4 (volume IV), April 1931, pp. 730-775.
} 
Protection of Helpless Infancy in 1912. Only then the State started to dispute the tuition of children whose parents didn't comply with their essential function, leaving them in evident abandonment and abuse. By then, the french jurist Clément Griffe stated that the right of the child should prevail over that of the father ${ }^{44}$. But the law of 1912 was a faux pas, as the norm's limitations made it practically inoperable ${ }^{45}$. Effective change was made with the promulgation of the Law of Minors, in 1928.

Even the priest Emilio Vaisse, defender of the traditional model of paternity, was in favor of the "revolution" introduced by the new legal frame of 1928. The child would no longer be submitted to the discretionary power of his father. Commenting on the text The rights of the child and the tyranny of his surroundings, a work written by the judge Samuel Gajardo to make the law 4.447 known, he was in favor of the idea exposed by the author: the State could not be indifferent to the intimacy of the home. A father that corrupts his children does not perform a private act, but one of social trascendence. Though he was in favor of defending the child of all that could corrupt him, he was suspicious of the enormous scope this defense of morality would have in hands of the State. All in all, he was inclined to applaud the benefits of the new approach $^{46}$.

Samuel Gajardo became an active promotor of the "rights of the child", from his first years as a judge of minors. In the book commented by Emilio Vaisse, for example, he cited the Declaration of the Rights of the Child, in one of its preliminary versions ${ }^{47}$. In his opinion, the new legislation involved a modern criterion of childhood, which did not consider the child to be a miniature man, following the idea of Robert Gaupp ${ }^{48}$. The complex mind of the child, especially of the one exposed to the dangers of his surroundings, had to be understood to act efficiently in a preventive manner and to reform his life gone astray.

Since 1925 it was stated that when a child was submitted to a trial, he could not be exhibited by the press. The law about publicity abuses penalized the publishing of information about crimes committed by minors, if it was not authorized by the judge (art.26) ${ }^{49}$. The law of minors of 1928 intensified these changes: it established a system that excluded those under 16 years of age of the penal system (and under certain conditions those under 20), eliminated the punishment and legal defense, established an agile verbal procedure and gave more power to the judge ${ }^{50}$. For judge Gajardo and his time, the legislation of minors was an indication of childhood's new status, as there was a scientific and at the same time benevolent, understanding and humanitarian criterion that was not limited to repress acts (that is to say, crimes), but also took in persons for their vulnerable condition inside society. In the decade of 1940, Gajardo would have an important role in the spreading of the new doctrine ${ }^{51}$.

Doctor Luis Calvo Mackenna was another promotor of the rights of the child. Besides participating in several national institutions, his international contacts made him especially sensitive to the subject. As we have already said, he had been an official delegate at the International American Institute of Protection to Infancy, which approved the Table or Decalogue of the Rights of the Child in 1927. In January of that year he had taken care of the direction of the House of Orphans, where he began to introduce many changes that notably diminished infant mortality, reduced the number of enrollments and made the adoption system easier. The personal work of Calvo Mackenna gave more results than the institutional transformation, which only began a few years later. In July 1929, also by his initiative, the name of House of Orphans of Santiago was replaced by that of House of the Child, to avoid an association to the stigma of abandonment. As we have seen, this was part of the rights proclaimed by the Institute ${ }^{52}$. It is said that Dr Calvo had signs put up in the whole establishment that read "The rights of the child are defended here",53.

\footnotetext{
${ }^{44}$ Cited by Armando Ricci Ferrari, La delincuencia infantil y los tribunales para menores. Estudio comparado de la ley $N^{\circ} 4447$ (Santiago, extended paper to apply for Bachelor's Degree at the Faculty of Law and Political Sciences, Universidad de Chile, Imprenta del Ministerio de Guerra, 1930), p.196.

${ }^{45}$ For example, the law only referred to legitimate children, only limited the power of fathers (not of mothers) and only on an economic sphere (affecting the legal figure of ius patria potestatis under the formula established by the Chilean Civil Code, and not the tuition and care of the children). Besides, it didn't establish a system of assistance to allow the State to take care of those children. There was other criticism due to the fact that the conditions that defined abandonment were very restrictive and hard to fulfill. There is a summary to the law of 1912 in Hipólito Letelier González, La protección de la infancia (Santiago, , extended paper to apply for Bachelor's Degree at the Faculty of Law and Political Sciences, Imprenta S.B., 1918), pp. 94-101.

46 "Crónica literaria" (Omer Emeth, pseudonym of Emilio Vaisse), in El Mercurio, Santiago, 26 December 1929, p.3.

${ }^{47}$ Strangely, he didn't cite the version of 1924, approved by the Society of Nations. Samuel Gajardo, Los derechos del niño y la tiranía del ambiente (Divulgación de la ley 4.447) Psicología, educación, derecho penal (prologue by Waldemar E. Coutts, Santiago, Imprenta Nascimento, 1929), pp. 41-50.

${ }^{50}$ About the new system, see Rojas, "Las acciones públicas hacia los niños, 1910-1930" (unpublished)

${ }^{51}$ Samuel Gajardo, Los derechos del niño, proclamados con motivo de la "Liga de los Derechos del Niñ̃o", el 25 de octubre de 1940 (Santiago, Impr. Universo, 1940); Los Derechos del niño, proclamados por la Unión Nacional de Protección a la Infancia en la semana del niño del Rotary Club el 19 de octubre de 1947 (Santiago, Impr. y Lit. Universo, 1947). The first text is not available.

${ }_{52}$ BIIAPI, No1 (volume.II), July 1928, pp. 70-86; [Casa Nacional del Niño], Memoria de la Casa Nacional del Niño. Breve reseña de su labor desde 1927 a 1934 inclusive (Santiago, Imprenta Casa Nacional del Niño, [1934]). The name of the instituttion in Santiago was changed following the Decreto Supremo 1340, 16 July 1929. Another decree, in 1930, extended the measure to the other orphanages in the country. Cited in Beneficencia, No7, August 1929, p. 385; Nº September 1929, p. 475; N¹4 March 1930 , p. 974.

${ }^{53}$ The reference to the signs in the National House of the Child appears in Nelson A. Vargas Catalán, Historia de la pediatría chilena: crónica de una alegría (Santiago, Editorial Universitaria, 2002), pp.180-182; and in Ricardo Cruz-Coke, Historia de la medicina chilena, electronic version http://docencia.med.uchile.cl/histmedicina/biograf.htm). None of them point out the origin of the information. Calvo Mackenna doesn't mention this when describing the innovations he made at the institution.
} 
Pediatricians actively pressed for the attainment of several topics related to the sanitary protection of infancy. The institutional environment that emerged in the 1920s preformed the powerful public health aparatus that extended into the next decade. One of the biggest successes was in the field of sanitary education, where medical preventive control of schoolchildren on a massive level was rehearsed for the first time. Promotion of maternal breastfeeding was also achieved. But this effort had already followed a path of several decades and the benefits of breastfeeding were mentioned in the convention of the protection of infancy of $1912^{54}$. The main change was the emphasis: the use of wet nurses was openly qualified as a crime and breastfeeding as a right of the child ${ }^{55}$.

In the childcare reader of the Chilean Society of Pediatrics, which was given out with the certificate of marriage from 1929 onwards, the right to maternal feeding was specified: "every mother can and should breastfeed her child as long as possible". "The child has a right to his mother's milk ${ }^{56}$. In 1931 breastfeeding was even established in the Sanitary Code as a right of the child ${ }^{57}$.

In the field of education, though schooling was not guaranteed for poor children (the necessary mechanisms for schooling assistance didn't exist), the concept from the oligarchy of two parallel education systems -one for the poor and one for the rich - was abandoned. No one objected (at least publicly) to the democratic character of education. In the 1920s the educational system was mainly considered to be a mechanism open to infancy as a whole and associated to the State's teaching function ${ }^{58}$. The idea that all children must (obligatorily) have access to school was imposed, both for socio economic reasons as political and psychological ones. Behind this policy was the idea that education was a prerrequisite for progress and the economic development of the country, the broadening of citizenship and institutional stability. But it was also a need of the children themselves, as it aided their integral development as persons.

The educational reform, that won support in the government as from 1924 and was initiated with the decree of December 1927, was one of the most active spaces in the circulation of the rights of the child. In 1928, in a document to parents, Luis Gómez Catalán defended the new concept of infancy that was gaining strenght: the child was no longer a small man, but a complex human reality that had to be studied and considered as a whole. In his opinion, traditional school "contradicted human nature". "They had made a school for small men. But the child is very different from the adult. Scientific investigations have proven it. The child is simply a child, that is to say, a being with a different intelligence, a different body, desires and aspirations than those of the adult. If one wishes to see an imperfect man in the child, one is doing nonsense. In the child there is no more than a child. The new school lovingly takes care that the individual lives his infancy, admitting an own and evident personality in the person at growth"59. Accepting this peculiar nature of the child meant that the school not only had to prepare him for his future social insertion, but promote that he experiment, as a child, his taking part in society. This is how for example the early assimilation of democratic values in children, including the notion of rights and obligations, was understood.

The new pedagogical emphasis criticized hierarchical relationships because the despised the capacities of persons. Traditional discipline was considered to be less and autodiscipline started to be valued. This tendency also extended to a familiar level. Several testimonies reveal the weight that children started to have inside the home, though this probably took place in different degrees. Punishment began to be unlegitimized, and paternal authority diminished. The former was even guaranteed by law when the use of physical punishment in students was outlawed ${ }^{60}$.

From the beginning of the $20^{\text {th }}$ century many children's organizations were encouraged, with different objectives (sanitary, recreational, civic and pedagogical).This was in the interest of the fatherland, and of the child's wellbeing. The intentions of these organizations were more or less welcomed and legitimized by society, in strong association with the adults' organizations that endorsed them. Old and new rivalries between freemasons, liberals, conservatives and communists were reproduced in this field. These organizations weren't aimed at stimulating the participation of children, but to guarantee an adequate socialization of them in the civic values that were considered to be under threat. The State enthusiastically supported the Association of Boy Scouts and the Youth Red Cross. At the opposite end there was a consolidation of the "pioneers" and rational schools, organized by communists, though for a

\footnotetext{
${ }^{54}$ Manuel Camilo Vial, Trabajos y actas del Primer Congreso Nacional de Protección a la Infancia, celebrado en Santiago de Chile del 21 al 26 de septiembre de 1912 (Santiago, Imprenta, Litografía y Encuadernación Barcelona, 1912), pp. 295-304.

${ }^{55}$ For example, Armando Zagal Anabalón, Lactancia y nodrizas asalariadas (ley Roussel) (Santiago, Extended paper to apply for M.D. Degree, Clínica de Enfermedades de Niños. Reader professor Luis Fuenzalida Bravo, Imprenta El Progreso, 1918), pp. 3-8 and 13.

This is also the tone of the paper "Nodrizas mercenarias", presented by J.M. Vergara Keller, at the Cuarto Congreso Panamericano, pp. 86-91.

56 "Cartilla de Puericultura de la Sociedad Chilena de Pediatría", in Revista Chilena de Pediatría, No4, abril/1930, pp. 213-216. "La Semana de la Madre", in Revista Chilena de Pediatría, No1, January 1930, pp. 51-53.

${ }^{57}$ According to this Code mothers milk was the "exclusive property of the child" and therefore the mother was bound to breastfeed him until the age of 5 months, unless she was ill. She could not breastfeed other people's children while her own had not reached that age, unless she had a medical certificate of fitness to habilitate her for that. In that case, it was compulsory to declare this before the sanitary authority, as were the parents or tutors of the second child to do as well (art.44). Sanitary code enacted by DFL 226, 15 May 1931, Diario Oficial, 29 May 1931.

${ }^{58}$ The subject was at the core of the debate that, after two decades, led to the enactment of the Law of Compulsory Primary Instruction in 1920. The institutional mechanism that consolidated social segregation was the existence of "preparatory courses" attached to public schools, which were slowly eliminated as from 1920, a process that was only completed at the end of the decade.

59 "Si usted no ayuda al magisterio, la educación es incompleta", in La Nación, Santiago, 8 April 1928, p. 13.

${ }^{60}$ About this phenomenon, one can consult our texts "Las imagenes de la infancia, 1910-1930" and "Los espacios de socialización de los niños, 1910-1930" (unpublished).
} 
brief period. The Catholic Church organized children's groups to resist the threats to faith. Many of these groups were eyed with suspicion by those who felt threatened by the type of socialization these organizations promoted. The adult organizations behind the youth organizations had a tendency to disqualify the objective of rival organizarions, emphatizing the "perverse" aims of the adults ${ }^{61}$.

The debate about religious education in schools also followed this criterion. Parents had freedom of conscience and were the ones who had to decide what moral formation their children would receive.

The politics of obligatory education and the strenghtening of the educational function of the State were critized by catholic groups (which favored the freedom of education) as well as by the communist and anarquist left (that tried to constitute its own educational system). Both groups were suspicious of the ideological objectives of education, but they finally had to yield before the crushing predomination of the new policies.

In the discussion about how to channel the "Social issue", one point all projects agreed on, was that of protecting child workers, and this is one of the things that were first enacted in the first laws of labor. Some sectors of society organized children's strikes as a protest to the high levels of childrens labor. Apparently, these strikes were organized spontaneously, without an active participation of adults. But they caused bewilderment because of the implicacies of this early way of socialization that promised a future of larger work upheavals.

The new labor laws acknowledged children the right to be protected from certain abuses by their employers, like excessive working hours or dangerous work conditions. But the State was the one entrusted with overseeing this, as children themselves weren't considered capable to have themselves represented in a direct manner ${ }^{62}$.

In very few occasions, children were summoned to defend certain rights, like the access to food. In response to the application of a tax to imported condensed milk, there was a protest in Antofagasta in which mothers and their children participated. Zig Zag magazine published the act and called it a "child meeting" 63 . The campaign was effective; the government soon established a maximum price for this product in the provinces where it was massively consumed ${ }^{64}$.

But the actions in favor of the material protection of infancy (including physical care, food and clothing) were the most frequent and mobilized the most resources. Just like in the $19^{\text {th }}$ century, this function was mainly entrusted to the private institutions that aided helpless children and were partially financed by the State. It was never considered to be a juridical obligation of the State to guarantee complete financing, but more of a moral obligation that showed the level of civilization of the country.

Sensibility towards poor children was transmitted to children of the upper classes, who learned charity at a young age. Child filantropy was developed in the first decades of the $20^{\text {th }}$ century, and was channeled in institutions like Bando de Piedad (Allegiance of Mercy). Soon child charity extended to the poor who were able to help those that were worse off. The Youth Red Cross, founded in 1923 and developed mainly in girls' primary schools, had this mission as well.

The right to children's happiness was also democratizad and started to be valued by the press and filantropic societies. This was channeled mainly in the giving of toys and organizing trips and matinés for the poor. Sensibility of this kind intensified during Christmas. We can see this in the following article, published in Zig Zag in 1926:

"I have seen children with no toys, children that have never picked up little remains of happiness left by others; those children listened with eyes enlarged by an unknown desire to the chords of the fanfare, the sounds of whistles and the bangs of the fireworks that expressed the joy of suburbia. I have seen those poor children, barefoot on a floor that burns, dirty, covered by rags; I have seen them playing in the streets in heaps of dirt, looking at life with a strange nostalgia. They are living a cruel nightmare, they bear the weight of a chain they don't deserve, they are sad at an age when other children, almost all children, are happy and the kings of their homes". ${ }^{65}$

But this appreciation of laughter and play overtook other spheres as well. One author even proposed not to ban children in prison from their childhood, "trifling their honest laughter, impeding their plays". Even in prison, "the child has to laugh and play", "the child must always be a child"

In the legal field, the idea of equality between lawful and unlawful children had some circulation, and was included in the texts by Gabriela Mistral and Rodríguez Fabregat. However, there were no major changes in the law, though there were some proposals to better the conditions of unlawful children. In 1916 for example, the member of parliament Ramón Briones Luco presented and initiative to establish a procedure of legal proof for illegitimate paternity. The proposal was very modest in its consequences, as it only tried to

\footnotetext{
${ }^{61}$ About this, see Rojas, Moral y prácticas cívicas.

${ }^{62}$ In practice, groups of children had been performing acts to demand their rights since before 1924, as we have registered in Los niños cristaleros: trabajo infantil en la industria. Chile, 1880-1950 (Santiago, vol. VI, Colección Sociedad y Cultura, Dibam, 1996) and Los suplementeros: los niños y la venta de diarios. Chile, 1880-1953 (Santiago, Ariadna Ediciones, 2006).

${ }^{63}$ Zig Zag, N¹048, 21 March 1925.

${ }_{64}^{64}$ El Mercurio, Santiago, 19 March 1925, p. 11

65 "Los que olvidaron los Reyes Magos" (Florencio Hernández), in Zig Zag, №1090, 9 January 1926.

${ }^{66}$ J. Félix Rocuart Hidalgo, La delincuencia infantil y los reformatorios de niños (Santiago, Imp. La Tarde, 1932), p. 22.
} 
establish a mechanism to assure the payment of alimony (which didn't affect the condition of being an unlawful child). However, this idea was not welcomed and the situation remained unchanged ${ }^{67}$.

The subject of unlawfulness was largely discussed in the first three decades of the $20^{\text {th }}$ century. At least 22 legal texts were written about this subject between 1901 and 1931, most of them between 1917 and $1931^{68}$. Several of these were only descriptive and detailed the legal consistency of the norms, but some of them were critical towards the existing laws for different reasons, and suggested changes ${ }^{69}$. All of them acknowledged the need to maintain the difference between lawful and unlawful children, but proposed some reforms, sometimes to make the norm coherent, or to make the condition of natural child more accesible or to eliminate the categories between unlawful children. For example, Varela critizised that the children of adulterous and incestuous parents (adultery and incest were crimes known as Dañado Ayuntamiento) were not considered to be natural children, when modern law tried not to accentuate the blame of adults on their offspring. He also criticized the fact that the legal proof to establish unlawful paternity was denied (both for the payment of alimony and attaining the condition of natural child), a norm that had been copied from napoleonic legislation. After a century of discussions about that prohibition, in his opinion it was more than proven that the measure was unfair and inefficient ${ }^{70}$.

Legitimacy had increased since the signing of the Civil Code. In 1855, there was an average of 226 illegitimate children for every thousand born, and in 1921 that number increased to $373^{71}$. Though this increment could not be blamed completely to a real deepening of the phenomenon, it was used as an argument against the effectiveness of the legislation ${ }^{72}$. Though there were no important institutional changes, illegitimacy began to decline at the end of the decade.

Letelier, another author, also critizised the fact that paternity depended on the father's will. Recognition of maternity was a much easier procedure, which showed discrimination. In his opinion, the initial arguments weren't valid (difficulty to prove paternity, avoiding unfounded accusations, containing ilegitimacy, avoiding a public scandal). According to Letelier the social effects of this were extremely harmful (infant mortality, abortions, infanticide, abandonment). There was social interest in not leaving these children in abandonment. To reverse this situation, he proposed to regulate the inquiry of paternity, and to give civil marriage preponderance over the religious one ${ }^{73}$. These and other texts justified a reform, but they were in favor of diminishing the legal differences, without eliminating them completely.

At the 1924 Pan American Convention of the Child, two papers advocated a legal reform to allow for the investigation of paternity. Finally it was agreed to propose that this investigation be allowed, but with certain conditions. It wouldn't be allowed if the mother had misbehaved and the procedure would only be authorized in some situations ${ }^{74}$. Though these discussions went on, actual changes were small. The only exception to this was the law of work accidents of 1924, which gave shared benefits for all children, be they lawful or unlawful ${ }^{75}$. The government, for its part, tried to stimulate the contracting of legal marriage through

\footnotetext{
${ }^{67}$ Raúl Varela Varela, Del reconocimiento voluntario de hijo natural y de la prueba judicial de su filiación (Santiago, , extended paper to apply for Bachelor's Degree at the Faculty of Law and Political Sciences, Universidad de Chile, Imprenta de San José, 1924), pp.

104-107.
${ }^{68}$ Between 1901 and 1916 we register tour texts; and between 1917 and 1931, eighteen. Rafael V. Ramírez A., De los hijos ilegítimos (1901); José Clemente Fabres, Derecho de los hijos naturales. De la nulidad y rescisión. Nulidad de un testamento cerrado. Efectos de la nulidad absoluta (1908); Moisés Poblete Troncoso, Legislación sobre los hijos ilegítimos (cuestión social) (1912); Fabio Ciangherotti, De los hijos ilejítimos no reconocidos solemnemente (1915); Juan Jerónimo Ortúzar Rojas, Paternidad ilejítima i su investigación (1917); Raúl Ferrada Riquelme, De los hijos naturales y de los simplemente ilejítimos: sus derechos hereditarios (1918); Enrique Tapia Cruzat, Los hijos ilejítimos en nuestra legislación (1920); Elías Letelier Fredes, De la filiacion ilejítima (1922); Víctor Concha Garcés, Hijos ilegítimos (1922); Rolando Merino R., Comentario al título IX, libro I, del Código Civil. De los derechos y obligaciones entre padres e hijos legítimos (1923); Raúl Boza B., Filiación natural (1923); Enrique Urrutia Manzano, Estudio sobre el artículo 272 del Código Civil y de la irrevocabilidad del reconocimiento (1923); Juan de Dios Valenzuela del Río, Los hijos naturales en concurrencia del cónyuge y hermanos legítimos (1924); Fernando Errázuriz Lastarria, De la investigación de la paternidad ilegítima (1924); Raúl Varela Varela, Del reconocimiento voluntario de hijo natural y de la prueba judicial de su filiación (1924); Alfonso Arancibia A., El problema de la indagación de la paternidad ilegítima y su solución en el Código Civil (1926); Carlos Verdugo Verdugo, La Investigación de la Paternidad Ilegítima (1927); Antonio Mancilla Cheney, De la Investigación de la paternidad ilegítima, especialmente en Chile, Francia, Bélgica, Suiza y Alemania (1928); Gregorio Fuentes O., De los hijos naturales (1929); Pablo Favero Latorre, Sistema de legitimación y de reconocimiento como naturales de los hijos ilegítimos (1929); Emilio Grant Benavente, La madre y los hijos ilegítimos ante el derecho civil y social (1930); Manuel Somarriva Undurraga, La filiación: estudio doctrinal y de legislación comparada (1931)

${ }_{69}$ Among those who set out criticism: Raúl Boza B., Filiación natural (Santiago, extended paper to apply for Bachelor's Degree at the Faculty of Law and Political Sciences, Universidad de Chile, Imprenta Comercial, 1923); Varela, Del reconocimiento voluntario, cited; Elías Letelier Fredes, De la filiación ilejítima (Concepción, , extended paper to apply for Bachelor's Degree at the Faculty of Law and Political Sciences, Universidad de Chile, Imprenta y Encuadernación Moderna, 1922).

${ }^{70}$ Varela, Del reconocimiento voluntario, pp. 56-58 y 94-134.

${ }^{71}$ Varela, Del reconocimiento voluntario, $\mathrm{p}$. viii.

72 The statistical register of legitimate and illegitimate children was probably seriously affected as from the law of civil matrimony, enacted in 1884. From then onwards, many religious marriages that didn't regularize their civil situation swelled the ranks of illegitimate children. This was noticed by Letelier, De la filiación ilejítima, pp. 3-4.

${ }_{73}^{73}$ Letelier, De la filiación ilejitima, pp. 3-4 and 45-51.

${ }^{74}$ It was proposed to allow investigation in a timeframe of two years (starting from birth). The right was limited to the cases of unlawful seduction, rape or violation and "notorious cohabitation"; also to the existence of documents where paternity was admitted. But the investigation would not be authorized if the behavior of the mother did not allow to suppose paternity during the cohabitation. Cuarto Congreso Panamericano, t. I, pp. 135-136; t.V, pp. 50-68. Varela, Del reconocimiento voluntario, pp.99-100.

${ }^{75}$ Ley 4055, 8 September 1924, Diario Oficial 26 September 1924, art.14.
} 
a policy of "persuasion" by the civil servants of the Civil Registry ${ }^{76}$. Only in 1935 some of the reforms that were posed ten years before, were introduced ${ }^{77}$.

Though there was public interest in the issue of child abandonment, there was no special preoccupation in giving adoption legal status. During the 1912 Convention on Protection of Infancy, a symposium by Alejandro Lira was in favor of legislating about this ${ }^{78}$. The issue was discussed in the Pan American conventions of the child in 1916, 1919, 1922 and 1924. During the latter, a Chilean delegate expounded about the subject and proposed a legal change ${ }^{79}$. But the idea didn't receive much response, as didn't a law project presented in June 1929 by Member of Parliament Rafael Moreno. This void in the Civil Code was only filled in $1943^{80}$. There was also no response to the project to rise the minimum age for sexual consent, which continued to be 12 years ${ }^{81}$.

Slowly the issue of the rights of the child was taking force outside of the circle of experts. The topic was included in the following editions of the Manual para las madres (Mothers'manual), by Lorenza. Though this publication usually gave practical advice about pregnancy, methods to rear children, feeding and childrens diseases, the first article referred to "The Rights of the Child", without following any of the already circulating texts. The first right was to "be born with a healthy body and a clear mind"; the second "to be loved and respected as an individual; [...] to develop the mind, body and soul; [...] to have protection from diseases, bad influences and people with bad intentions, and [...] to have some opportunities in life"; and the third, the right to "the environment in which best to develop his powers and talents"

Though the concept of the rights of the child was somehow well received among intellectuals and politicians of the beginning of the $20^{\text {th }}$ century, the situation of children and the strong ideological debate caused the issue to develop in contradictory and unstable ways.

\section{Resistances}

The spreading of the rights of the child met with different forms of resistance. Some had their origin in the radicalized atmosphere of the time, which could not conceive that the extreme sensibility towards poor children coexisted with a great indifference to the demands of their worker parents. The poor areas most related to the revolutionary left didn't think that the actions of the State or philantrophy, much less the declarations on childrens rights, could solve the marginality of poor children. For that reason, these declarations were scarcely refered to.

One of the texts that commented on the first declaration of the rights of the child known in Chile, in 1912, is an example of this point of view. The article was directed to "the poor children" and noted on the lack of consistency of the declaration, made by "brainy humanitarian - educationalists" "just for fun". Abandoned children were assured that they would have a right to the sun, air and food, but "with the detail that, if overtaken by hunger you take a bread to feed yourselves or a piece of cloth to cover your flesh, then those brainy sirs that recognized your rights in theory, will call you uneducated, rascals and other epithets that the reigning hypocresy applies to those who have nothing, and they will egg the police on to arrest you as if it was the most natural thing in the world". Poor children with a home and responsible parents didn't have it any better. If their parents learned that their children had a right to life and demanded an increment of salary "those same sirs, in the name of order and established legality, will call them demanding and disruptive" and if they took something to alleviate the hunger of their little ones, they would call them as thieves. Poor children lived emaciated by diseases, "afflicted and tormented by the desire to posses a toy or little suit", like the children of the rich. Clothing, food and toys are banned to them by the institutions that are respected and

\footnotetext{
${ }^{76}$ At the moment of contracting matrimony, the officer of the civil register had to hint at the need of inscribing already born children, a procedure with no cost. This policy had already been brought up before 1930, with the implementation of registers in far away areas. "The government is determined to achieve the legalization of Chilean family", in La Nación, Santiago, 21 November 1930, p.1; "Por la mujer y por los hijos" (editorial), in La Nación, Santiago, 24 November 1930, p.3.

77 Changes were scarce: the concept of illegitimate children of "dañado ayuntamiento" was eliminated (leaving only two: simple illegitimate and natural children) and the investigation of illegitimate maternity and paternity was authorized, but only for the payment of tuition. Ley 5750, sobre pago de pensiones y represión del abandono de familia, 30 November 1935, Diario Oficial. 2 December 1935, Justice Ministry . Only in 1952, with the law 10.271 (29 February 1952, Diario Oficial., 2 April 1952) the condition of natural child was modified and a procedure for the recognition of natural children was established, among other changes.

${ }^{78}$ Vial, Trabajos y actas, pp. 511-515.

${ }^{79}$ Paper by Carlos Estévez Gazmuri, in Cuarto Congreso Panamericano, volume V, pp. 9-16. Luis Soto Bórquez, La adopción en nuestra legislación civil (Santiago, , extended paper to apply for Bachelor's Degree at the Faculty of Legal and Social Sciences, Universidad de Chile, Imp. La Tarde, 1929), pp. 74-75.

${ }^{80}$ Soto, La adopción, pp. 7-8, 74-75, 89, 96-101. Among the few previous texts written about the subject: Luis R. Valenzuela, La adopción ante la lei chilena. Estudio hecho a propósito del primer caso de adopción que se presenta ante nuestros tribunales (1885); J. M. Ide Martínez, La adopción en el derecho romano i en el Código Civil alemán. Necesidad de establecerla en Chile (1901). The first law of adoption was only enacted in 1943 (Law 7613, of 11 May 1943, Diario Oficial 21 October 1943).

${ }^{81}$ The Society of Nations didn't propose an increment in age, because several countries resisted this, but there was some favorable climate to this, as a way to avoid early pregnancies and accentuate the penalization of human trafficking. About this, the article by Eugenia Scarzanella can be consulted, "Los pibes en el Palacio de Ginebra: las investigaciones de la Sociedad de las naciones sobre la infancia latinoamericana (1925-1939)", in Estudios Interdisciplinarios de América Latina y el Caribe, volume 14, №2, July-December 2003 (available on http://www.tau.ac.il/eial/XIV_2/scarzane.html ) In Chile the legal change came only in 2003, when the age of sexual consent was incremented to 14 years.

${ }^{82}$ This text appears in the edition of 1929, the only one we have been able to consult. The Manual was published since 1922, we don't know if with the same contents. Lorenza, Manual para las madres (no autor, unpublished), p. 17. The cited edition has an introduction by Cora Mayers, and for the statistics it contains, it must be from 1929.
} 
revered by the same sirs that at one time proclaimed your rights to prove that they walk along with the current of the century" ${ }^{\prime 3}$.

But, even though the formal declaration of rights wasn't well received by anarchists and socialists, these groups were openly in favor of limiting parental authority, erradicating punishment, democratize schools; better the material conditions and pursuing children's happiness in quite a radical manner. In fact, it was mainly inside anarchist and communists groups that the most radical approach to the rights of the child was forged. They even considered promoting active ways of social participation and recognizing the child's autonomy.

In this sense, the political left was both dependent of the romantic ideal of childhood (which translated in their demand of more protection of the child) as of a broad model of democracy that considered limiting all ways of inequality between people (based not only on a difference of class, but also of sex, ethnic groups and age). Obviously, according to them this fight would finally be solved with the triumph of the revolution, but many proposed a substantial advance in this matter through education. That was the proposal, for example, of Francisco Ferrer.

At the opposite side, more traditional groups were critical of the new status of infancy, particularly of the excessively condescending treatment of children. Several texts recounted in an ironic or openly critical tone, the new condition created by "the king of the house" and the loss of paternal authority ${ }^{84}$. Roxane, one of the best known figures preoccupied with children, lamented in 1925 the predominant tendency to please children without boundaries, a process that annulled all principle of authority. In his opinion, there were plentiful "spoiled" girls and boys, who were selfish and whimsical ${ }^{85}$. This tone makes one suppose that cultural resistances were important, and that this change of conduct didn't become widespread. In 1918, Ernesto Montenegro compared the way in which children were treated in Chile and the United Status and remarked upon the differences: in our cities, a mother holding her child didn't receive the attentions that were common in North American society, as he had been able to confirm ${ }^{86}$.

Some sectors still questioned motherly love. For example, they reproached the high classes for still widely using wet nurses, and considered this to be an evident proof of the little interest mothers had in their children ${ }^{87}$.

As for the popular sectors, Luis Calvo Mackenna spoke out against the "astonishing, disconcerting and brutal indifference with which the mothers of the common people come to" the House of Orphans "to definitely abandon their children, many of them of a few months of age". This indifference was reflected in the "unconceivable calm" with which they insisted on having their children accepted; the "crushing coldness" with which they saw them disappear out of their sight for ever and gave them up "as a thing they give" for they conceived their children as property; "they reclaimed the knitted jersey and little crocheted boots that warmed the child as if it was the most natural thing in the world, all without any gesture of remorse, compassion of pain" 88 .

Calvo Mackenna questioned the idealization that in his opinion was made of "the kindness of the mothers of the lower classes", though he admitted that the large majority of them had "a high level of affection" for their children. A generalized exception "would be an aberration of nature". However, his experience in policlinics, hospitals, Gota de Leche (Milk drop, an organization that distributed milk and other necessities to poor children ), asylums and orphanages, "in real contact with the people, the uncultured and miserable people of the outskirts and suburbs", taught him a different reality:

"we know that there are mothers that punish the small disobedience of a child that is just starting to walk, keeping him locked up in the dark for hours, on bread and water; we know that the whip is used as a disciplinary action to correct insignificant faults, it is rolled around a tender little head, making the face bleed with the hard knot at the end; we know that the thick bar of a door often breaks the tender head that forged an innocent folly; and finally, we know that if their angry little lips violently complain of these inhuman treatments, they can be closed infernally with a hot iron or with the hot coal that heated that same iron on the brazier. I'm not saying that these facts are frequent, but I'm stating that they aren't as exceptional as is generally thought" ${ }^{\prime \prime}$.

These "denaturalized" mothers that were capable of this "tremendous harshness" with their children of a few years of age, didn't have the least compassion towards the newborn, "that new being they don't even feel belongs to them and don't even feel the least shadow of affection for" 90 .

As one can see, according to this doctor's evaluation large part of the responsibility befell on the mother, as if the father didn't exist. According to Calvo Mackenna, though the social context of poverty explained the abandonment of children in orphanages, the mothers' lack of interest was also important. In any case, the testimony of Calvo Mackenna was credible because he didn't generalize.

\footnotetext{
83 “A los niños pobres" (Juan Cordero), in El Despertar de los Trabajadores, Iquique, 24 November 1912, p.1.

${ }^{84}$ An example of this is the article "Las matinés infantiles" published in 1902, in which the absurd whims of children were caricatured.

(El Ferrocarril, Santiago, 22 October 1902). For his part, Emilio Vaisse wrote in the magazine Familia against the loss of authority inside the home. Familia, №54, June 1914, p.1.

${ }^{85}$ Roxane, "Notas sociales", in Zig Zag, No1084, 28 November 1925.

86 "Su graciosa majestad el niño" (Ernesto Montenegro), in Zig Zag, №716, 9 November 1918

${ }^{87}$ For example, "Nodrizas mercenarias" (J.M. Vergara Keller), in Cuarto Congreso Panamericano, pp. 86-91

${ }^{88}$ BIIAPI, No 1 , July 1928, p.74

${ }^{89}$ BIIAPI, No 1 , July 1928, p.74

${ }^{90}$ BIIAPI, No 1 , July 1928, p.74
} 
In the public sphere, public collections destined to poor children and social fundraising activities, received a large amount of means and filled up pages in magazines and diaries. Initially a sphere of socialization for the higher classes became a massive activity, with a large participation. However, this process also caused resistances because of the excess of public collections ${ }^{91}$.

The governor of Santiago regretted the scarce response he received when he asked for the help of the higher classes, which was a big difference from the climate that surrounded the 1924 Pan American Convention of the Child. In an interview published in Zig Zag, Alberto Mackenna reproached this inconsequence. Olga Cousiño had been the only good hearted person he had found in Santiago. "There may be others; but I don't know them". For two years he did everything possible to give protection to 50 boys the police had picked up from the street and nothing worked out. A lady of high society even rented them a miserable place for a very high price. "An institution that proclaims its allegiance to mercy thought well of my proposal to establish a link between poor and rich children; trying to have each group give something in favor of the other. They talked, organized, published articles, celebrated a convention of the child, named delegates, national and international ambassadors. Everything came out of this initiative except what we asked for and needed: money, help. Without Olga Cousiño's generosity, the vagabond children would have starved to death on the streets. This has to be said"92.

When La Nación newspaper wrote about infantile mendacity in December 1928, it showed the multiple circulating arguments. At first, it showed preoccupation for the social danger this entailed (a focus of delinquency and the loss of beings who were potentially useful to society). Then, it showed interest in the children themselves: "The future destiny of these poor wretches isn't less worth considering. With no responsibility for being the way they are, they have a right to society's preoccupation, to have society save them and take them away of the somber luck they seem predestined to". But then it paid attention to the esthetic consequences they caused: "And they are also a disagreeable and discrediting stain for society. Dirty, in rags, cadging, with a crude way of talking, they give a not very flattering idea of the society they marginally live in, but to which they actually belong" "93. The interest in children themselves seemed to vanish rapidly.

Reversing the high infant mortality was a central objective of public policies since the end of the $19^{\text {th }}$ century, and this tendency increased with the surge of pediatrics. Here there are also multiple interests at stake: international prestige, the strengthening of the nation's economic capacity and the stronger value placed on infancy. Despite the high levels of mortality, the State's strategy didn't consider diminishing the high birth rates. On the contrary, the size of families was seen as a factor of progress. The pro birth policy still prevailed. Even the Chilean partisans to eugenics were careful to propose control measures and not to mention abortion, sterilization nor the use of birth control techniques ${ }^{94}$.

Birth control was a subject that arose simultaneously with the valorization of infancy, though there is no direct link between the two. Some feminist currents made it into their banner, just like some anarchist and socialist groups. An article published in 1908 in the workers periodical La Palanca, of feminist and socialist tendencies, defended birth control ${ }^{95}$. On may $3^{\text {rd }} 1913$, Clara de la Luz (probably a pseudonym) gave a conference in the Democrat Center of Santiago with a clear neo - Malthusian influence, in particular of the Spanish magazine and editorial Salud y Fuerza (Health and Strength) ${ }^{96}$. Many of their leaflets circulated in Chile, among them Strike of wombs! Practical measures to avoid numerous families (1905, with several reissues), by the anarchist Luis Bulffi, and Conscientious generation, by Frank Sutor. This illustrated work included "prints and anatomical figures, apparatus and objects of sexual preservation" The Spanish editorial informed about the use of the "uterine shutter", already invented by then ${ }^{97}$. According to their proposal, the defense of the child, woman and humanity was guaranteed by a new attitude towards reproduction. Birth control would make the liberation of humanity possible.

In 1913, a new article in favor of birth control was published in El Despertar de los Trabajadores (The Workers' Awakening) of Iquique. It was written by Víctor Soto Román, a political leader of ambiguous anarchist and democrat adherence ${ }^{98}$. Though we don't know the level of acceptance of these campaigns, propaganda did not cease in the following years. In 1926 and 1927 the anarchist periodical El Sembrador (The Sower) included texts in favor of birth control ${ }^{99}$.

\footnotetext{
${ }^{91}$ Zig Zag, No955, 9 June 1923

92 "Cincuenta niños vagos", in Zig Zag, N¹063, 4 July 1925.

${ }_{93}$ Cited by Ricci, La delincuencia infantil, pp. 36-38.

${ }^{94}$ The Law of Defense of the Race of 1925 limited marriage between persons that could transmit hereditary flaws or diseases, but didn't mention abortion nor the sterilization of the sick.

95 Article signed by Yedra, in La Palanca, August 1908, p.19, cited by Asunción Lavrín, Mujeres, feminismo y cambio social en Argentina, Chile y Uruguay (Santiago, vol. XXXIX, Colección Sociedad y Cultura, Dibam, 2005), pp. 171-172.

${ }_{96}$ La mujer y la especie (Santiago, Imprenta Lee y CA, 1913).

97 The cited texts are mentioned, to be sold, on the back cover of La mujer y la especie. They aren't to be found at the National Library. Some are available in digital version on the site "Proyecto de Filosofia en Español": http://www.filosofia.org/pcero.htm. In particular, the text by Luis Bulffi can be consulted: http://www.filosofia.org/aut/001/1909huvi.htm

98 "La familia" (Víctor Soto Román), in El Despertar de los Trabajadores, Iquique, 22 February 1913, p.2. About the polemic figure of Soto Román, see the text by Sergio Grez Toso, La alborada de "La Idea" en Chile. Los anarquistas y el movimiento obrero, 1893-1915 (unpublished).

99 The articles were signed by G. Hardy, pseudonym of Gabriel Giroud, a neomalthusian anarchist and disciple of Paul Robin. El Sembrador, Valparaíso, 20 November 1926 and 15 January 1927., cited by Lavrín, Mujeres, pp.173-174 (the original isn’t available)
} 
By then, that same periodical condemned the resistance by sanitary authorities of the distribution of the leaflet Conscientious generation by Sutor that - as is to be seen - still circulated. The polemic text was blamed for conspiring against morals and honest customs, as it showed birth control techniques in detail ${ }^{100}$.

Birth control wasn't accepted by some social areas. An editorial in La Federación Obrera (Workers' Federation), published in July 1923, was completely against these practices. Commenting on a conference by Doctor Alejandro del Río, the article criticized the changes that had been taking place in the field of maternity. "Half a century back the general functions of maternity were satisfied according to the prescriptions of nature and when an indiscretion would cause scandal, the woman hid herself but regularly fulfilled the mandate of nature, that gave one more son to the fatherland, though he would grow up lost in a bunch of anonymous people". That mother fulfilled her womanly function and motherhood strengthened her for life's blows. But today high society has imposed other superfluous preoccupations and woman doesn't devote herself to satisfy the physiological needs of humanity. In the ruling classes, the fact of being a mother had become a crime, even among married women. Woman resorted to "the most dreadful and anti natural resources to avoid conception". In this way, nature was twisted and corrupted, which led to the physical weakening of population. But this social evil, "a result of bourgeois refinement", had also invaded the poorer classes, teaching them how it was possible to live and enjoy themselves "without the wretched load of children". The editorial stated that it was necessary to go back to the times in which motherhood was "dignified and lofty", and this would only be attained with revolution, that would return humanity to "the dignified and pure state that capitalism has tried to forget"101

As one can see, the defense of the rights of the child wasn't really at the basis of this debate about birth control. It had more to do with the defense or detraction of maternity as an inalienable function of woman. In fact, the main argumentation of pro birth policies wasn't centered on a validation of the child, but on the interest of nation and the respect for nature.

Beyond the polemics, the use of birth control techniques was more common among the high and middle classes of the population, than in the lower classes. This is what Doctor Moisés Amaral stated during a conference in 1917, in which he energetically condemned its use. To avoid circulation, he excused himself from giving details of the "many numerous" devises used by men and women ${ }^{102}$.

Despite these efforts, the size of families' weren't altered and birth rates remained stable, between 38 and 41 per thousand. Changes would begin only as from the decade of the $1960 \mathrm{~s}^{103}$.

For the church, children were a blessing and their number should not be limited. For the State, its pro birth policy was guaranteed through the promotion of large families. For popular culture, pregnancy was an unavoidable and unpredictable consequence. In words of Moisés Amaral, the poor "see the arrival of their numerous offspring with the biggest calm and say with resignation: 'Children are the inheritance of the poor" ${ }^{\prime \prime 24}$. It is probable that this atmosphere was the most propitious to maintain the high birth rate. However, though many mothers and fathers resigned themselves to the arrival of new children, an indeterminate amount of them practiced abortions or even infanticide.

The texts about abortion invariably disqualified this practice, and regretted that there were intentions to legalize it under certain conditions in other countries. By then, its legitimacy was in fact discussed in Europe (to protect the life and health of the mother, in the case of pregnancy caused by rape), a tendency that culminated in 1920 when it was completely legalized in the Soviet Union. In Chile there were no legal changes regarding abortion. However, it was practiced in silence, be it with chirurgical techniques or traditional methods that included the use of herbs. In the press there were even ads of boarding houses run by midwifes that helped women who were to give birth during the first few months, under total reserve. With their silence, authorities made things easier. Despite the penalties established by the law, the cases practically didn't get to the courts. Whether it was true or not, there was a feeling that the practice of abortion was augmenting ${ }^{105}$.

According to the statistics, there was an average of 3700 abortions per year in the country, though Doctor Isauro Torres estimated there were about 2000 (of the "criminal" sort only in Santiago). Torres was of the opinion that abortions were practiced both by high and lower classes, though its incidence was higher in the first group, for reasons of "honor" and "morality"106. Doctor Amaral was of a similar opinion, but his emphasis was stronger: the poor "rarely" resorted to abortive maneuvers ${ }^{107}$.

\footnotetext{
${ }^{100}$ El Sembrador, Valparaíso, 20 November 1926, p. 2, cited by Lavrín, Mujeres, p. 174 (the original isn't available).

101 "Frutos de la indolencia", in La Federación Obrera, Santiago, 31 July 1923, p. 1.

${ }^{102}$ Moisés Amaral [Martínez], Los anticoncepcionales y el aborto criminal. Conferencia dada en la Sociedad Científica de Chile, en sesión de 28 de agosto de 1917 (Santiago, Imprenta Franco-Chilena, G. Gregoire, 1917), pp. 6-9.

${ }^{103}$ The mortality rate was relatively stable for several decades. Though the birth statistics are more recent, they can also serve as a reference to measure the magnitude of the change: the global birth rate went from 5,4 children per woman of fertile age (15 to 49 years) in 1960 to 1,9 in 2003.

${ }^{104}$ Amaral, Los anticoncepcionales, pp. 8-9

${ }^{105}$ Amaral, Los anticoncepcionales, p.6; Adolfo Jofré Rossel, El delito del aborto (Santiago, , extended paper to apply for Bachelor's Degree in law and political sciences at Univesidad de Chile, Imprenta Comercial, 1922), pp. 3-5, 15-18 and 57-59; Luis Bórquez A., Estudio sobre el aborto (Santiago, , extended paper to apply for Bachelor's Degree at the Faculty of Law and Political Sciences, Universidad de Chile, Imprenta Comercial, 1922), pp. 55-56; Fernando García Huidobro Domínguez, El aborto (Santiago, extended paper to apply for Bachelor's Degree at the Faculty of Law and Political Sciences, Universidad de Chile, Imprenta y Librería Artes y Letras, 1925), pp. 11-15; Isauro Torres Cereceda, Mortinatalidad de Santiago (abortos i nacidos -muertos) (Santiago, thesis for M.D. Degree, Clínica Universitaria de Obstetricia, Prof. Pardo Correa, Imprenta El Progreso, 1918), p. 37.

${ }^{106}$ According to the official information, 3.476 were performed in 1908 and 3.914 in 1919. Bórquez A., Estudio sobre el aborto, p. 55.
} 
The practice of infanticide also received public attention. Different from abortion, which was penalized but tacitly accepted, infanticide was more severely condemned. The penalties applied in the 1840s still included a ritual that symbolized the seriousness of the crime: the body was placed in a bag with an animal (dog, rooster, or snake) to destroy its entrails and then it was thrown in the river. Though this practice was later abolished, there were still numerous condemnatory verdicts, in comparison to that of abortions. When the penalization of abortion and infanticide was discussed in 1874, the idea that prevailed when considering extenuating circumstances was that both situations were different. The law had to proceed more severely against infanticides ${ }^{108}$.

The debate between specialists about the scope of infanticide and abortion has been long. According to some, it was a general practice before Christianity, but was then contained for religious reasons. The re is no definitive evidence about this. In any case, it seems clear that moral condemnation increased. The predominant thesis is that after the $18^{\text {th }}$ century the practice of abandonment became widespread, which diminished the importance of abortion and infanticide ${ }^{109}$. At the beginning of the $20^{\text {th }}$ century there was no report of an expanding infanticide. On the contrary, there was preoccupation for abandonment. But soon the reception of children in orphanages was made less easy, and for a brief period the phenomenon was contained. Calvo Mackenna was behind this reform from 1927, as we have seen ${ }^{110}$.

\section{Final words}

Though the massive diffusion of the doctrine of the rights of the child is relatively recent, the concept has had a long development. Different views have been present in the texts that circulated since the end of the $19^{\text {th }}$ century and there is no progression to be seen among them, since some of the first documents included pretty radical views for that time, followed by other, more moderate ones.

Not all declarations were known in Chile. Those with a larger circulation were that of Spain of 1912, of Geneva of 1924 and the one signed in Montevideo in 1927. Strangely, the document written by Gabriela Mistral in 1927 had a larger circulation in the rest of Latin America than in Chile.

These texts proclaimed the right to live in satisfactory material and sanitary conditions, to receive protection and care, love and consideration, elemental education, and in some of them the right to joy and happiness was even emphasized. Though there was not always an explicit reference, sometimes it was stated that the State had to guarantee some of these rights.

In that same time there were several initiatives that came together in recognizing a larger participation of the State, especially in sanitary matters. This was also reflected in the work policies, which displaced the traditional liberal policies. In fact, the first proposals for regulation were centered on the situation of child workers. In educational matters, there wasn't only interest to amplify the schooling among popular sectors; there was also an accentuation of the value of freedom and democratic participation in the educational process. For its part, private philanthropy, observed in growing ways non-material aspects: joy, for example, had to be common to all children, independently of their social condition.

The doctrine of the rights of the child, which gave its first steps in these decades, started to show a certain sense of exceptionality in its way to justify these rights among the infantile population. Far from assimilating them to a condition of "human", equaling their status to that of the adult (who in those years fought to have similar rights recognized), it accentuated the peculiar character of the child (for his frailty and innocence) and his strategic importance for the future of society.

\section{Sent October 30th 2006}

Torres made his estimates from a projection of the cases atended at the Maternity Ward of San Borja hospital. He discarded the usefulness of the official statistical information at his disposal. Torres, Mortinatalidad, pp. 35-37.

${ }^{107}$ Amaral, Los anticoncepcionales, p.13.

${ }^{108}$ Manuel Domínguez Larraín, El infanticidio desde el punto de vista penal y médico legal (Santiago, , extended paper to apply for Bachelor's Degree at the Faculty of Law and Political Sciences, Soc. Impr. y Lit. Universo, 1923), pp. 19, 32-33, 55-65 and 66. Jorge Ceardi Ferrer, El infanticidio bajo el punto de vista penal y médico legal (Valparaíso, , extended paper to apply for Bachelor's Degree at the Faculty of Law and Political Sciences Universidad de Chile, Talleres Gráficos Proteo, 1926), pp. 18-19.

${ }^{109}$ René Salinas and Manuel Delgado, "Los hijos del vicio y del pecado. La mortalidad de los niños abandonados (1750-1930)", in Proposiciones, $\mathrm{N}^{\circ} 19,1990$, pp. 44-54.

${ }^{110}$ BIIAPI, Nº1 (t.II), July 1928, pp. 70-86. 
Translated by Cristina Labarca Cortés

Translation from Historia (Santiago), Santiago, v.40, n.1, p. 129-164, Jun. 2007. 